УДК $342.3(7 / 8)$

DOI https://doi.org/10.32850/sulj.2019.4.2.21

\title{
ПРЕЗИДЕНТСЬКА МОДЕЛЬ ПРАВЛІННЯ: РОЛЬ ГЛАВИ ДЕРЖАВИ І ЙОГО МІСЦЕ В ДЕРЖАВНО-ПРАВОВОМУ МЕХАНІЗМІ
}

Хімченко С. В.

Як показує аналіз, в останні десятиліття більшість демократичних держав почали орієнтуватися лише на установку відносного посилення виконавчої влади. Основною причиною цьому $\epsilon$ те, що суспільство через застосування різних форматів правління має потребу в авторитарній виконавчій владі. Звертаючи увагу на чю проблему, зазначимо, що поняття форми правління повинне виходити із двох начал. По-перше, як правило, джерелом влади повинен бути глава держави і його конституційно-правовий статус. Так, якщо глава держави одержував владу у спадщину, це, безумовно, - монархія, якщо від народу або від його представників, то - республіка. По-друге, юридичні відносини повинні складатися лище між вищими органами влади. У світлі викладеного існує необхідність проаналізувати конституційно-правовий інститут глави держави у випадку президентської форми правління. У статmі автором досліджується президентська форма правління й у цьому ракурсі вивчається конституційно-правовий статус і місце президента в різних країнах.

Ключові слова: президент, інститут глави держави, президентська форма правління, принцип поділу влади.

Как показывает анализ, в последние десятилетия большинство демократических государств начали ориентироваться только на установку относительного усиления исполнительной власти. Основная причина этого - тот факт, что общество из-за применения различных форматов правления нуждается в авторитарной исполнительной власти. Обращая внимание на эту проблему, отметим, что понятие формы правления должно исходить из двух начал. Во-первых, как правило, источником власти должен быть глава государства и его конституционно-правовой статус. Так, если глава государства получал власть по наследству, это, безусловно, - монархия, если om народа или от его представителей, то - республика. Во-вторых, юридические отношения должны складываться только между высшими органами власти. В свете изложенного существует необходимость проанализировать конституционно-правовой институт главы государства при президентской форме правления. В статье автором исследуется президентская форма правления, и в этом ракурсе изучается конституционно-правовой статус и место президента в разных странах.

Ключевые слова: президент, институт главы государства, президентская форма правления, принцип разделения властей.

Investigating the problems that arise when correlating the presidential form of state government with the model of the constitutional-legal institute of the head of state, first of all, we would like to make a reservation that we prioritize for ourselves the analysis, not only of the peculiarities of the legislation of foreign countries, but also the realities of political and economic life of the investigated of the state. We believe that this approach will only have a positive impact on the quality of the current scientific publication.
As the analysis shows, the concept of the form of state government is not identical in the scientific literature. Yes, A.O. Mishin at one time argued that the nature of the form of government depends only on the organization of higher state power, more precisely, on the determination of the legal position of one higher body of state power - the head of state.

According to the analysis, in recent decades, most democratic states have begun to focus only on establishing a relative strengthening of executive power. The main reason for this is that, because of the use of different formats of government, society needs an authoritarian executive. Drawing attention to this problem, it should be noted that the concept of the form of government must come from two principles. First, as a rule, the source of power should be the head of state and his constitutional and legal status. So, if the head of state received power by inheritance, it is certainly a monarchy, if from the people or from its representatives, then - the republic. Secondly, legal relations should be formed only between the highest authorities. The article explores the presidential form of government and in this perspective examines the constitutional and legal status and place of the president in different countries.

So, we can conclude that a firm separation of powers with an additional system of "checks and balances", in other words, worked on the principle of "everything is mutual" or "we are all equal, and we have the same right to you as you to us".

Key words: president, head of state institute, presidential form of government, principle of separation of powers.

Постановка проблеми. Досліджуючи проблеми, що виникають під час співвідношення президентської форми державного правління з моделлю конституційно-правового інституту глави держави, насамперед, хотілося $б$ сказати, що пріоритетним для себе ми ставимо проведення аналізу не тільки особливостей законодавства закордонних країн, а й реалій політичного й економічного життя досліджуваної держави. Вважаємо, що такий підхід лише позитивно відіб' $є$ ться на якості теперішньої наукової публікації.

Як показує аналіз, у науковій літературі поняття форми державного правління не має ідентичного характеру. Так, А.О. Мишин свого часу стверджував, що характер форми правління залежить лише від організації вищої державної влади, точніше, від визначення правового положення одного вищого органа державної влади - глави держави [1, с. 119].

Із визначенням цього автора можна було погодитися, адже не варто приховувати той факт, що конституційно-правове положення глави держави впливає не тільки на форму правління, а й на форму політичного режиму. Разом із тим варто визнати, що подібне виключення з визначення співвідношення вищих органів державної влади робило її трохи недопрацьованою. 
Думаємо, саме тому згодом самим А.О. Мишиним це визначення було уточнено. Форма правління, з його погляду, $\epsilon$ «найбільш зовнішнім вираженням змісту держави, зумовленим структурою і правовим положенням вищих органів державної влади» [2, с. 79].

Виклад основного матеріалу. Більш широке поняття форми державного правління було надане А.Г. Орловим. Форма правління, на його думку, - це «організація верховної влади в державі, що характеризується джерелом влади й принципами взаємин органів влади між собою та з населенням» [3, с. 170].

Цю ж думку висловлювала й Л.В. Жильська. Учений вважала, що форма правління - це елемент форми держави, що визначається правовим положенням, порядком формування й функціонування вищих органів державної влади (насамперед - глави держави), характером їхніх взаємин між собою та з населенням [4, с. 7].

Варто помітити, що деякі правознавці під формою правління розуміли організацію всієї держав-

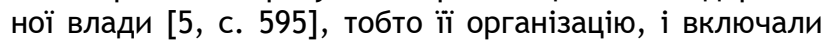
в зазначену дефініцію, крім вищих органів держави, й інші державні органи [6, с. 96, 32, 125, 79, 121]. На нашу думку, цього робити було не можна, адже форму правління можна визначити лише конституційно-правовим положенням голови держави.

Цікавою представляється не зовсім зрозуміла для нас позиція відомого конституціоналіста В.Є. Чиркіна. В одних своїх працях він стверджував, що «форма правління - це лише характеристика структури і взаємин вищих органів державної влади (насамперед, глави держави, парламенту й уряду), їхньої ролі в керуванні країною» $[7$, с. 75, 150]. В інших працях В.Є. Чиркін зміст цієї дефініції трактував ширше, ототожнюючи при цьому поняття форми правління з керуванням державою [8, с. 140] в конституційно-правовому змісті, відзначаючи, що тут «важливо враховувати не тільки особливості зв'язків глави держави, парламенту й уряду, а і роль інших центральних органів (наприклад, контрольних), а також місцевих органів держави, використання різних методів, прямих і зворотних зв'язків у процесі керування» [9, с. 258-259].

Можна зазначити, що таке трактування, як ми вже відзначали, вимагало враховувати основи всього державно-правового механізму, наприклад, конституційноправове положення й роль різних видів органів (влади, керування, контролю, правосуддя й ін.) у його структурі, реальну роль місцевих органів держави [10, с. 18] та ін. Вважаємо, що такий погляд потребує уточнення.

Вивчення чималої кількості наукових праць дає нам можливість стверджувати, що обов'язкового зв'язку органів державної влади з народом і зв'язку з іншими органами (місцевими) влади під час трактування форми правління пропонували дотримуватися ряд не тільки вітчизняних (радянських: російських, киргизьких), а й закордонних учених. Так, наприклад, у цьому був упевнений і М. Дюверже. Французький учений був переконаний у тому, що традиційне включення в поняття форми правління тільки відносин між вищими державними органами $\epsilon$ невиправданим ступенем. Він вважав, що підставою для нової соціологічної класифікації повинна стати ступінь участі громадян у керуванні державою. М. Дюверже вкладав однаковий зміст у поняття форми правління й політичного режиму [11, с. 22].

Цієї ж позиції дотримувався і Й. Благож. Чеський дослідник розглядав дану проблему не без включення двох елементів:
1) відносин вищих органів у процесі здійснення державної влади й керування;

2) відносин громадян і держави, що входять у поняття форми правління [12, с. 195].

Однак, вважаємо, що ані А.Г. Орлов, ані Л.В. Жильська, ані В.Є. Чиркін, ані М. Дюверже, ані Й. Благож, ані інші дослідники, які дотримуються цієї позиції, не праві. Адже відносини органів державної влади між собою та з населенням - це вже елемент політичного режиму, але ніяк не форми правління. Так, із цього приводу, наприклад, відомий російський учений Б.О. Страшун зазначав, що поняттям «політичний режим» позначається лише система прийомів, методів, форм, способів здійснення політичної (включаючи державну) влади в суспільстві [13, с. 165]. Тож виходить, що політичний режим розкривається лише як функціональна характеристика влади. Вона не може не відбиватися на правових формах держави і їі відносин із суспільством і окремою людиною, урегульованих, насамперед, конституційним правом.

У цьому контексті заслуговує на увагу твердження зазначеного вченого про те, що нерідко саме політичний режим $\epsilon$ причиною фіктивності відповідних правоположень, зміст яких вихолощується практикою здійснення державної влади або які цією практикою порушуються [14]. Інакше кажучи, Б.О. Страшун приходив до думки, що незалежно від того, яка форма в тій або іншій державі встановлена, найголовніше - установити, наскільки вона ефективно діє. І в цьому плані він був правий. Наприклад, у минулому на пострадянському просторі навіть в умовах закріплених в окремих державах змішаних форм правління на практиці були очевидними лише ознаки безмірної президентської влади.

Вважаємо, що поняття форми правління повинне виходити із двох начал. По-перше, як правило, джерелом влади повинен бути глава держави і його конституційно-правовий статус. Так, якщо глава держави одержував владу у спадщину, це, безумовно, - монархія, якщо від народу або від його представників, то - республіка. По-друге, юридичні відносини повинні складатися лише між вищими органами влади, але не між населенням і органами влади.

У світлі викладеного бачимо необхідність проаналізувати конституційно-правовий інститут глави держави у випадку президентської формі правління. Як показує аналіз, в останні десятиліття більшість демократичних держав почали орієнтуватися лише на установку відносного посилення виконавчої влади. Основна причина цього - те, що суспільство через застосування різних форматів правління має потребу в авторитарній виконавчій владі. Як вірно відзначає А.Ш. Арутюнян, проблема стала посилюватись ще й тим, що у «швидко мінливих ситуаціях, за якими не встигає парламент, виконавча влада стала діяти, виходячи з реальних вимог життя. У виконавчої влади $\epsilon$ в наявності дискреційні повноваження, які з різним ступенем інтенсивності існують майже у всіх країнах» [15, с. 46].

Варто визнати, що під час вибору тієї або іншої форми правління, зокрема визначаючи формат взаємин президента з іншими органами державної влади, кожна держава самостійно, з огляду на свої історичні умови й національні особливості, визначає для себе зручну й більш прийнятну модель правління. Про це йдеться далі.

Вивчення підтверджує, що появі президентського типу республіки доктрина конституційного права повинна дякувати США. Саме Конституція американ- 
ської держави стала першим юридичним документом, що вперше реалізував ідею поділу влади з використанням системи стримувань і противаг. Поряд із поділом влади ключовими концептуальними ідеями Конституції $\epsilon$ федералізм і судовий контроль, що включив незабаром і перевірку конституційності правових актів. Як стверджують американські дослідники, перераховані принципи здавались «батькам-засновникам» настільки самоочевидними й безперечними, що вони не одержали прямого словесного закріплення в тексті Конституції, пронизуючи, однак, весь іï зміст [16, с. 10].

Президент як керівник країни одержував свої повноваження від народу, тобто обирався безпосередньо населенням, що робило його, як мінімум, рівним за ступенем легітимності вищому представницькому органу, такому як парламент. Більше того, у президентській республіці виконавча влада несла відповідальність не перед парламентом, а безпосередньо перед президентом. Вона була надана йому практично в особистій якості. Варто відзначити, що президент як глава виконавчої галузі влади на власний розсуд підбирав і заміняв кандидатури членів уряду, самостійно визначав повноваження всіх посадових осіб і структуру виконавчого апарата.

щодо володіння депутатським мандатом, то ані глава держави, ані інші члени уряду на це не мали права. Як було сказано, одна галузь державної влади була чітко відділена від іншої. 3 огляду на це законодавча влада цілком була «дарована» тільки парламенту. Разом із тим це не означало, що президент як глава держави ніякої участі в цьому не брав. Він мав право законодавчої ініціативи, або право внесення пропозицій щодо законодавства (до речі, варто звернути увагу, що це не поширювалося на класичну президентську республіку як США). Більше того, саме президентові була відведена функція підписання й оприлюднення законів, він мав право відкладеного вето. Відповідно до конституції або на основі делегування йому відповідних повноважень президент мав право видавати нормативні акти у вигляді указів, розпоряджень, декретів, які за своєю юридичною чинністю хоча й уступали законам, але за змістом практично нічим від них не відрізнялися.

Маючи право впливати на прийняті парламентом закони, президент водночас не мав права розпускати парламент, а парламент не мав права вотуму недовіри президентському правлінню. Достроково припинити повноваження президента вищий законодавчий орган країни міг тільки за допомогою складної процедури (висування імпічменту) за державну зраду й здійснення ним тяжкого злочину. Усе це свідчило про те, що глава держави й парламент були «приречені» на співіснування і співробітництво протягом усього строку своїх повноважень.

Таке співробітництво у президентській республіці зобов'язувало формувати третю (судову) галузь влади спільно. У своєму класичному вигляді судді були не змінювані й здійснювали свої функції довічно. Вони мали право тлумачення «Основного закону країни» і виконували контроль за його дотриманням. Відповідно до цього Вищий орган судової влади міг визнати будь-який нормативно-правовий акт президента або парламенту неконституційним і скасувати його.

I нарешті, що стосується питання національної безпеки, то під час президентської форми правління тільки глава держави був Верховним Головнокомандуючим і мав право введення надзвичайного та воєнного стану, яке в умовах парламентарної республіки переважно належало Прем'єр-міністрові (керівникові уряду).

Отже, можна зробити висновок, що мав місце твердий поділ влади 3 додатковою системою «стримувань і противаг», інакше кажучи, працювали за принципом «все взаємно», або "ми всі рівні, і ми маємо таке ж право на вас, як і ви на нас».

Мабуть, такий формат взаємин був оптимальним, адже в цьому разі кожна галузь державної влади, володіючи «козирем» відповідальності стосовно іншої влади, підвищувала свій ступінь «життєздатності». Але, з іншого боку, ми вважаємо, що такий розклад був оптимальним тільки в разі, якщо президент такої країни переслідував лише інтереси держави, а не особисті. У протилежному випадку життєдіяльність державної влади була приречена.

Обґрунтувавши, що твердий поділ влади із системою стримувань і противаг мав найчіткіше виявлення в американсько-правовому механізмі, ряд дослідників все-таки стверджували про «переплетення» останнім часом повноважень галузей державної влади США. Як показує державна практика, в законотворчій діяльності все активнішу участь брала виконавча влада США $[17$, с. 46]. Так, наприклад, у щорічних посланнях глави держави фактично формулювалася програма майбутньої законодавчої роботи Конгресу. Більше того, поширення придбали нормотворчість Президента й делеговане законодавство, необхідність яких виводилася з конституційних повноважень глави держави.

Була правотворчою і діяльність Верховного суду США із тлумачення Конституції й законів, унаслідок чого створювалися прецеденти, що мають значення конституційних і законодавчих норм. Не залишалася недоторканною і сфера діяльності виконавчої влади. Конгрес нерідко приймав резолюції і приватні білі «з незвичайних, випадкових i другорядних питань законодавства», які легко б могли бути дозволені в адміністративному порядку. Судові органи за допомогою наказів могли зобов'язати виконавчі органи і їхні посадові особи виконати ті або інші дії або втриматися від їх здійснення [18, с. 97-115]. Саме тому, як зазначали у своєму дослідженні Ю.А. Дмитрієв і А.М. Миколаїв, не може бути «й мови про який-небудь абсолютний поділ влади, про чіткий поділ їхньої компетенції» [19, с. 133].

Висновки. Мабуть, такий висновок мав право на існування, але, з іншого боку, не варто забувати про те, що в такий спосіб органи державної влади не «замірялися» на основні своїх функцій. Можливо, такими діями вони взаємодоповнювалися, попередньо обговорюючи свої дії, здійснювали єдину політику? Адже таке можливо фактично. Під час визначення якого-небудь політичного курсу президент і Конгрес США заради ефективності могли виробити ефективну єдину тактику створення й реалізації тих або інших програм, національних нормативно-правових актів тощо. Але це ніяк не означало, що глава держави «замірявся» і заміняв представників судової влади, які, здійснюючи сформульовані в Конституції США функції (наприклад, охорона права), мали право бути джерелами правотворчості. 


\section{Література}

1. Мишин А.А. Государственное право буржуазных стран и стран, освободившихся от колониальной зависи-мости. Москва, 1976.

2. Мишин А.А. Конституционное (государственное) право зарубежных стран. Москва : «Белые альвы», 1996.

3. Государственное право буржуазных стран и стран, освободившихся от колониальной зависимости. / Под ред. И.П. Ильинского, М.А. Крутоголова Москва : Юрид. лит., 1979.

4. Жильская Л.В. Институт главы государства : монография. Санкт-Петербург : Изд-во СПб университет МВД России, 2008.

5. Проблемы общей теории права и государства / Под общ. ред. В.С. Нерсесянца. Москав, 1999.

6. Комаров С.А. Общая теория государства и права : учебник. 3-е изд. Москва : Юрист, 1997.

7. Теория государства и права: Курс лекций / Под ред. М.Н. Марченко. Москва, 1998.

8. Опритов Я.И. Специфика формы государственного правления современной России: теоретико-правовое исследование : дис. ... канд. юрид. наук. Самара, 2001.

9. Черданцев А.Ф. Теория государства и права : учебник для вузов. Москва : Юдайт, 1999.

10. Фаткуллин Ф.Н. Проблемы теории государства и права : курс лекций. Казань, 1987.

11. Якушин В.М. Государство переходного типа (вопросы теории). Казань : Лыбидь, 1991.

12. Государственное право буржуазных стран и стран, освободившихся от колониальной зависимости / Под ред. Б.Л. Стародубского и В.Е. Чиркина. Москва, 1977.
13. Чиркин В.Е. Конституционное право зарубежных стран : учебник, 2-е изд. Москва : Юрист, 2000.

14. Чиркин В.Е. Современное государство. Москва : Международные отношения, 2001.

15. Сравнительное конституционное право : учеб. пособие / Отв. ред. В.Е. Чиркин. Москва : Международные отношения, 2002.

16. Чиркин В.Е, Тихонов А.А., Рябое СВ. Формы государства в буржуазных странах Латинской Америки. Москва : Наука, 1986.

17. Благож Йозеф. Формы правления и права человека в буржуазных государствах. Москва : Юрид. лит., 1985.

18. Страшун Б.А. Конституционное (государственное) право зарубежных стран. Т. 1. Москва : БЭК, 1993.

19. Арутюнян А.Ш. Конституционно-правовой статус президента Республики Армения : дис. ... д-ра юрид. наук. Москва, 1997.

20. Мишин А.А., Власихин В.А. Конституция США. Политико-правовой комментарий. Москва, 1985.

21. Гаджи Задэ Элънур Ахлиман. Конституционные модели формы правления и институт президентства в странах СНГ : дис. ... канд. юрид. наук. Волгоград. 2005.

22. Леттер Д. Принцип разделения властей и система сдержек и противовесов в Конституции Соединенных Штатов. Верховенство права. Москва, 1992.

Хімченко С. В., кандидат юридичних наук, доцент кафедри господарського, трудового права та цивільно-правових дисциплін Міжрегіональної Академії управління персоналом 